\title{
Nutritional Therapy In Ischemic Stroke Patient With Type 2 Diabetes Mellitus : A Case Report
}

\author{
Cipuk Muhaswitri ${ }^{1}$, Diyah Eka Andayani ${ }^{2}$, Taufik Mesiano ${ }^{3}$
}

1. Residency Programme in Clinical Nutrition Science, Department of Nutrition, Faculty of Medicine, Universitas Indonesia, Jakarta, Indonesia

2. Department of Nutrition, Faculty of Medicine, Universitas Indonesia-RSUPN dr. Cipto Mangunkusumo, Jakarta, Indonesia

3. Department of Neurology, Faculty of Medicine, Universitas Indonesia-RSUPN dr. Cipto Mangunkusumo, Jakarta, Indonesia

muhaswitri@yahoo.com

\begin{abstract}
Introduction: The prevalence of stroke in Indonesia increased from 8.3 per 1000 population in 2007 to 12.1 per 1000 population in 2013, based on Riset Kesehatan Dasar (RISKESDAS) 2013. Diabetes mellitus (DM) is an independent risk factor and can be modified. Hyperglycemia that occurs in the acute phase of stroke is associated with an increase in mortality and poor clinical outcome after stroke. Moreover, stroke patients are at risk of developing hypoalbuminemia due to poor intake and the presence of a chronic inflammatory process.

Methods: A 66-year-old female patient with third recurrent ischemic stroke, history of uncontrolled DM, conciousness based on GCS is E3M5Vaphasia, Nasogastric tube (NGT) was inserted and there was a right facial nerve paralysis and bilateral hemiparesis. Nutritional status of patient is obese-1. During follow up period, the patient's blood glucose level ranged from $194 \mathrm{~g} / \mathrm{dl}-345 \mathrm{~g} / \mathrm{dl}$. Nutrition therapy is given with a target of $1350 \mathrm{kcal}(32$ $\mathrm{kcal} / \mathrm{kg}$ ). Its composition consists of $15 \%$ protein, $25 \%$ fat and $60 \%$ carbohydrate (preferred complex carbohydrates), in the form of DM-specific formula containing inulin and monounsaturated fatty acid (MUFA). This nutritional therapy was administrated six times per day via enteral pathway, followed by the administration of micronutrients of vitamins $C$, $B$ and folic acid.

Result: During follow up period, the patient tolerated well with the diet. After the 14 days hospitalization, there was improvement of blood glucose level $(<200 \mathrm{~g} / \mathrm{dL})$. Albumin level increases from $2.5 \mathrm{~g} / \mathrm{dL}$ to $2.9 \mathrm{~g} / \mathrm{dl}$ by the nutritional therapy containing protein more than $1.2 \mathrm{~g} / \mathrm{kg} /$ day.

Conclusion: Administering a diet with the recommended composition and formula helps control hyperglycemia and improve hypoalbuminemia in patients that can improve the patient's clinical condition.
\end{abstract}

Keywords: stroke, hyperglycemia, hypoalbuminemia, nutrition

\section{ABSTRAK}

Pendahuluan: Prevalensi stroke di Indonesia meningkat dari 8,3 per 1.000 populasi pada 2007 menjadi 12,1 per 1.000 penduduk pada 2013, berdasarkan Riset Kesehatan Dasar (RISKESDAS) 2013. Diabetes mellitus (DM) merupakan faktor risiko independen dan dapat dimodifikasi. Hiperglikemia yang terjadi pada fase akut stroke dikaitkan dengan peningkatan mortalitas dan hasil klinis yang buruk setelah stroke. Selain itu, pasien stroke berisiko mengalami hipoalbuminemia karena asupan yang buruk dan adanya proses inflamasi kronis. Metode: Seorang pasien wanita berusia 66 tahun dengan stroke iskemik berulang ketiga, riwayat DM yang tidak terkontrol, kesadaran berdasarkan GCS adalah E3M5Vaphasia, 
tabung Nasogastric (NGT) dimasukkan dan terdapat kelumpuhan saraf wajah kanan dan hemiparesis bilateral. Status gizi pasien adalah obesitas-1. Selama masa tindak lanjut dan pemantauan, kadar glukosa darah pasien berkisar antara 194 g / dl-345 g / dl. Terapi nutrisi diberikan dengan target $1350 \mathrm{kkal}(32 \mathrm{kkal} / \mathrm{kg}$ ). Komposisinya terdiri dari $15 \%$ protein, 25\% lemak, dan 60\% karbohidrat (dengan memilih karbohidrat komplek), dalam bentuk formula spesifik DM yang mengandung inulin dan asam lemak tak jenuh tunggal (MUFA). Terapi nutrisi ini diberikan enam kali per hari melalui jalur enteral, diikuti dengan pemberian mikronutrien seperti vitamin C, B dan asam folat.

Hasil: Selama masa pemantauan, pasien dapat mentoleransi diet dengan baik. Setelah 14 hari dirawat di rumah sakit, terjadi perbaikan kadar glukosa darah ( $<200 \mathrm{~g} / \mathrm{dL})$. Kadar albumin meningkat dari 2,5 g / dL menjadi 2,9 g / dl dengan terapi nutrisi yang mengandung protein lebih dari $1,2 \mathrm{~g} / \mathrm{kg} / \mathrm{hari}$.

Kesimpulan: Pemberian diet dengan komposisi dan formula yang direkomendasikan membantu mengendalikan hiperglikemia dan meningkatkan hipoalbuminemia pada pasien yang dapat memperbaiki kondisi klinis pasien.

\section{Kata kunci: stroke, hiperglikemia, hipoalbuminemia, nutrisi}

\section{INTRODUCTION}

The prevalence of stroke in Indonesia increased from 8.3 per 1,000 population in 2007 to 12.1 per 1000 population in 2013, based on Riset Kesehatan Dasar (RISKESDAS) $2013^{1}$. Diabetes mellitus is an independent risk factor and is a modifiable risk factor for both ischemic and hemorrhagic stroke. Hyperglycemia occured in the acute phase of stroke is associated with an increase of mortality and poor clinical outcome after stroke attack $^{2}$. Hyperglycemia will induce calcium imbalance and increase reactive oxygen species (ROS) in the neurons, hence triggering apoptosis mechanism. In post stroke condition, hyperglycemia decrease perfusion by decreasing the availability of nitric oxide (NO) which is an important mediator for vasodilatation. It also increases the inflammatory mediators which causing edema and bleeding through disruption of the blood brain barrier and degadration of white matter. Those process will deteriorate the functional outcomes ${ }^{3}$.

Nutrition along with physical activity, hypoglycemic drug therapy and education are the four pillars in the management of diabetes mellitus. One of the goals of nutrition therapy is to control blood glucose levels ${ }^{4}$.
Hypoalbuminemia in stroke patients can be caused by malnutrition, or the presence of comorbidities such as liver and kidney insufficiency, heart failure and malignancy. Another cause of hypoalbuminemia in stroke patients is chronic inflammation. Systemic inflammation will reduced albumin levels, due to reduced protein synthesis and increased protein catabolism. Hypoalbuminemia in stroke patients when treated will increase the risk of infection, death, and poor clinical outcome $^{5}$. Hypoalbumineia is an indirect systemic condition such as malnutrition or other underlying disease and neurological condition which will affect the ability to recover from acute stroke. ${ }^{6}$ The aim of administering the nutrition therapy to these patients is to control blood glucose levels and increase albumin levels in stroke patients with DM type 2.

\section{CASE REPORT}

This was a case report of a 66-year-old female patient with third recurrent ischemic stroke, and history of uncontrolled of DM. Patient was hospitalized between October 18 to November 7, 2018. Patient conciousness based on GCS is E3M5Vaphasia, NGT was inserted and there was a right facial nerve paralysis and bilateral hemiparesis. Nutritional status of 
patient is obese-1 (body mass index/ BMI 25,3 $\mathrm{kg} / \mathrm{m}^{2}$ ), categorized based on the asia-pacific BMI. The patient's blood glucose level ranged from 194 to $345 \mathrm{~g} / \mathrm{dl}$. Nutritional therapy with standard protocol was administrated with a target of $1350 \mathrm{kcal}(32 \mathrm{kcal} / \mathrm{kg})$, with a composition of $15 \%$ protein $(1,2 \mathrm{~g} / \mathrm{kgBW}-1,5$ $\mathrm{g} / \mathrm{kgBW}), 25 \%$ fat and $60 \%$ carbohydrate (preferred complex carbohydrates), in the form of DM-specific formula hospital containing inulin and monounsaturated fatty acid (MUFA), with a frequency of six times administration per day, through the enteral pathway, accompanied by the administration of micronutrients of vitamins $\mathrm{C}, \mathrm{B}$ and folic acid. Patient also receive Novorapid ${ }^{\circledR}$.
The patient tolarates well with its diet. The initial blood sugar level is more than 200 $\mathrm{g} / \mathrm{dL}$. Daily blood glucose level were checked every Monday, Wednesday and Friday, three times each day. The improvement of blood glucose was found after 14 days hospitalization $(<200 \mathrm{~g} / \mathrm{dL})$ (figure 1). Carbohydrate intake of patient during the monitoring period is $58-60$ $\%$ from total energy requirement.

The result of initial Albumin levels on $3^{\text {rd }}$ day was $2.5 \mathrm{~g} / \mathrm{dL}$ (hypoalbuminemia) and it decreased on $6^{\text {th }}$ day $(2,45 \mathrm{~g} / \mathrm{dL})$. There was an improvement of albumin level after conducted the corection $(2,66 \mathrm{~g} / \mathrm{dL})$ (figure 2$)$. Patient's protein intake during monitoring is 1.2 $\mathrm{g} / \mathrm{BW} /$ day $-1,5 \mathrm{~g} / \mathrm{kgBW} /$ day.

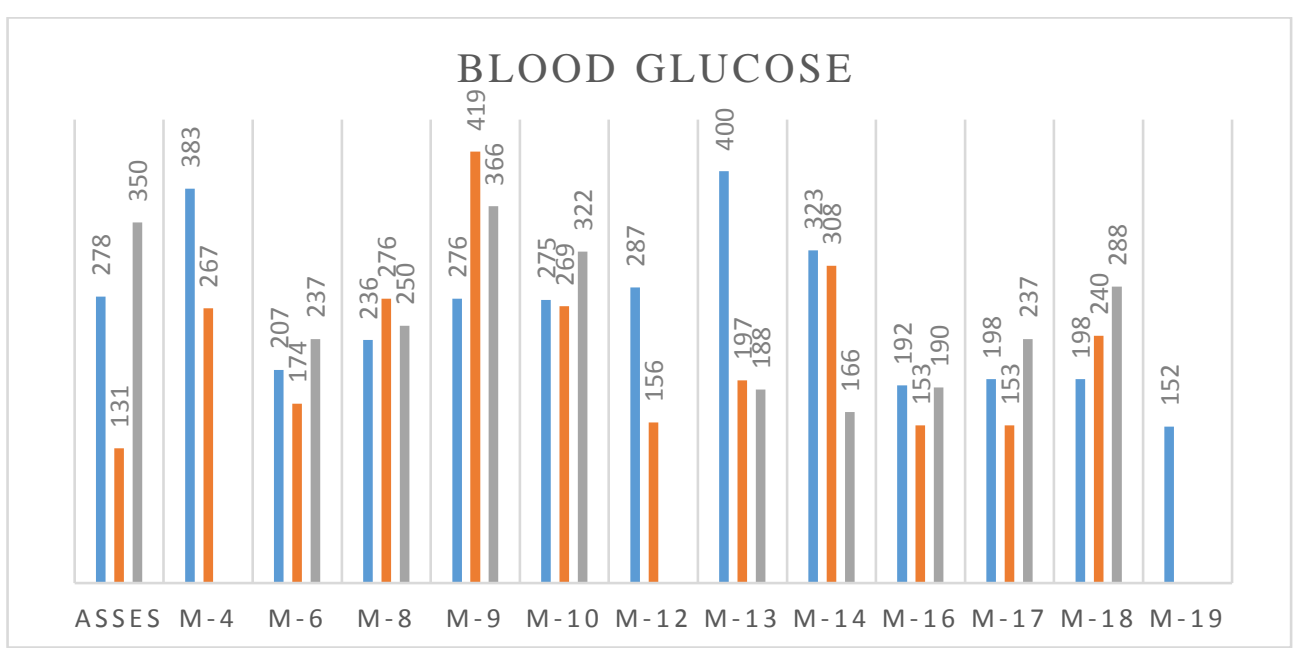

Figure 1. Blood Glucose Level During Hospitalization

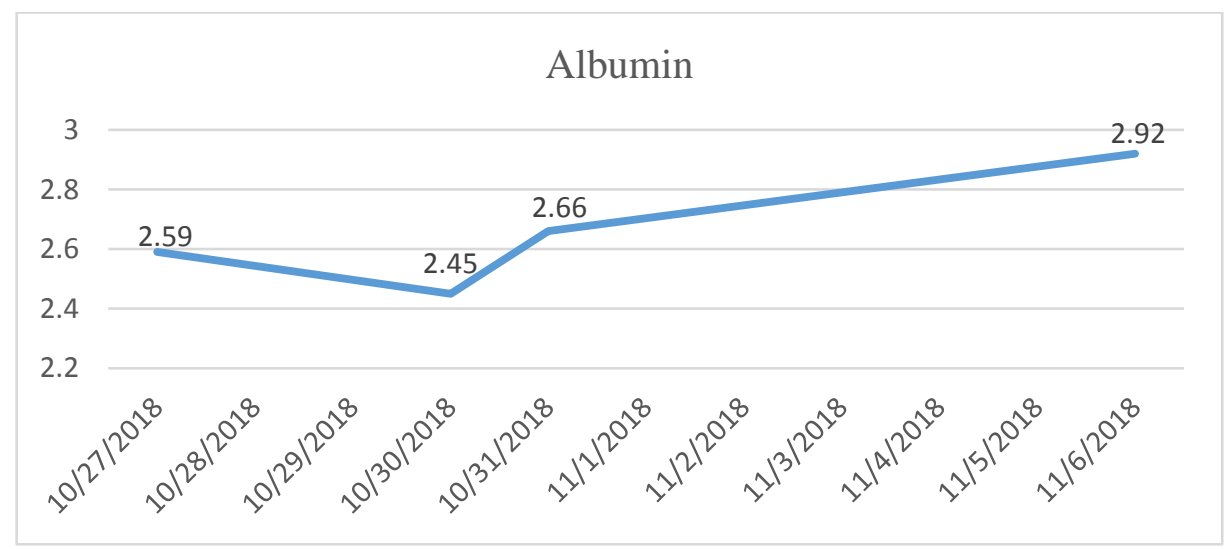

Figure 2. Albumin Plasma Level During Hospitalization 


\section{DISCUSSION}

The patient was a 66-year-old woman with nutritional status obes - 1 who came with a decrease in consciousness four hours before being admitted to the hospital. Patients with recurrent strokes and suffering from type 2 diabetes and uncontrolled hypertension since twenty years ago. The patient was consulted to the clinical nutrition specialist on the 9th day of hospitalization.

Modifiable risk factors for stroke are the most important, because intervention strategies that aimed to improve these factors can reduce the risk of stroke. Modifiable risk factors can be further divided into medical conditions such as hypertension, diabetes mellitus, hyperlipidemia, atrial fibrillation and obesity. While behavioral risk factors such as smoking, diet, lack of physical activity and alcohol consumption. ${ }^{7}$ Risk factors that can be modified in these patients are hypertension, diabetes mellitus, obesity, diet and lack of physical activity.

Diabetes mellitus (DM) is an independent risk factor for stroke with a 2fold increase in risk, and stroke also causes $20 \%$ of deaths in DM patients. Pre-diabetics also have a high risk of stroke. The duration of diabetes is also associated with an increased risk of stroke. DM patients affected by stroke tend to be younger, and have a higher prevalence of other stroke risk factors. Lifestyle modification and medical therapy in diabetic patients have been shown to reduce the risk of stroke. ${ }^{7}$ This patient has been suffering from diabetes for twenty years but does not control her diet. The antidiabetic used is insulin but the patient's caregiver did not remember the dose. According to the family, the classic symptoms of diabetes (polyphagia, polidipsia and polyuria), blurred vision and weight loss were absent.
Physiologically, plasma glucose concentrations are maintained in a narrow range, although there are fluctuations between glucose demand and availability, with interactions regulated by insulin secretion and tissue sensitivity to insulin (especially in the liver). This mechanism is impaired in type 2 diabetes, because there is a disruption of insulin secretion through pancreatic $\beta$ cell dysfunction, and impaired insulin action through insulin resistance. ${ }^{8}$ The American Diabetes Association recommendation (ADA) in establishing a diagnosis of DM is based on examination of $\mathrm{HbA} 1 \mathrm{c}>6.5 \%$, fasting blood glucose $>126$ $\mathrm{mg} / \mathrm{dL}$, blood glucose $>200 \mathrm{mg} / \mathrm{dL} 2$ hours after loading of 75 gram glucose, random plasma glucose of $>200 \mathrm{mg} / \mathrm{dL}$ with classic symptoms. Diabetes mellitus will cause long-term complications such as macrovascular and microvascular. Complications in DM are retinopathy, nephropathy, peripheral neuropathy which causes people with diabetes to be prone to diabetic ulcers, autonomic neuropathy so that symptoms arise in the gastrointestinal tract, genitourinary, heart and blood vessels and disturbed sexual problems. ${ }^{9}$ Random plasma glucose level of this patients was 232 $\mathrm{mg} / \mathrm{dL}$ without classic symptoms of diabetes. The diagnosis of DM is established by $\mathrm{HbA} 1 \mathrm{c}$ value of $6 \%$ and also the patient has suffered from previous DM.

Carbohydrate administration is adjusted to the ADA recommendations with the aim of controlling blood glucose in patients with type $2 \mathrm{DM}$, which is $45-65 \%$ of total calories. Whole wheat, vegetables and fruits, and legumes are the recommended types of carbohydrates, which are high in fiber and low in glycemic load. Glycemic control will be good and insulin sensitivity will increase with low food glycemic index. ${ }^{9}$ Carbohydrates are given to these patients according to the recommendations of ADA, which is $60 \%$ with mostly complex 
carbohydrates. Patients were given hospital diabetes formula in the form of blended and liquid food diabetes. Both formulas contain 5 grams of inulin in every $1000 \mathrm{kcal}$. Inulin is a group of carbohydrates which are classified as soluble and fermented fibers. Inulin helps control diabetes and its complications by improving lipid and glycemic parameters. ${ }^{10}$ In addition, these two liquid foods also contain 14 grams of olive oil in $1000 \mathrm{kcal}$,as well as MUFA which also helps improve glycemic control and blood lipid levels. A study have found that the diabetes-specific enteral formula reduced postprandial glycemia, mean glucose, glycemic variability, and shortacting insulin requirements.. ${ }^{11}$ This patient was consulted to clinical nutrition specialist to get a standard diabetes formula, but her blood glucose did not improve. On the 6th day of hospitalization, the formula was changed to refined DM food and a commercial diabetes specific formula.

Protein is given as much as $1.2 \mathrm{~g} /$ $\mathrm{kg}$ body weight because the patient is also diagnosed with acute kidney injury (AKI). This amount of protein is in accordance with the recommendations of Kidney Disease Improving Global Outcome (KDIGO). ${ }^{12}$

Based on laboratory tests the patient's albumin levels are also low. Hypoalbuminemia in stroke patients can be caused by malnutrition, or the presence of comorbidities such as liver and kidney insufficiency, heart failure and malignancy. Another cause of hypoalbuminemia in stroke patients is chronic inflammation. Systemic inflammation will reduce albumin levels, due to decreased protein synthesis and increased protein catabolism. Hypoalbuminemia is a predictor of more severe stroke. ${ }^{5}$ For this patient in addition to pharmacological approach to relieve systemic inflammation and treat comorbidities, protein is given at levels slightly above the minimum recommendation, to help increase albumin levels.

During treatment, the patient's contact ability was inadequate. Blood glucose level improved on the 14th day, which is below $200 \mathrm{mg} / \mathrm{dL}$, during the morning checks. The patient initially only received Novorapid®, on the 9th day lantus is added. The albumin level at initial assessment was $2.59 \mathrm{~g} / \mathrm{dL}$, then dropped to $2.45 \mathrm{~g} / \mathrm{dL}$ and rose again to $2.66 \mathrm{~g} / \mathrm{dL}$ after being corrected with the addition of 1 kolf albumin. Albumin levels at the last examination were $2.92 \mathrm{~g} / \mathrm{dL}$. During treatment, administration of protein was maintained slightly above $1.2 \mathrm{~g} / \mathrm{kg}$ body weight. This approach makes the patient reach the Total Energy Requirement until the time the patient is discharged from the hospital.

\section{CONCLUSION}

Giving a diet with the recommended composition and formula helps control hyperglycemia and improve hypoalbuminemia in patients that can improve the patient's clinical condition.

\section{REFERENCES}

1. Badan Penelitian dan Pengembangan Kesehatan. Riset Kesehatan Dasar. Kementrian Kesehatan. 2013.

2. Chen R, Ovbiagele B, Feng W. Diabetes and Stroke: Epidemiology, Pathophysiology, Pharmaceuticals and Outcomes. Am J Med Sci. 2016;351:3806.

3. Li WA, Moore-Langston S, Chakrabourty T, Rafols JA, Conti AC, Ding Y. Hyperglicemia in Stroke and Possible Treatments. Neural Res. 2013; 35:479-91

4. Asif M. The prevention and control the type- 2 diabetes by changing lifestyle and dietary pattern. J Educ Health Promot. 2014;21;3.

5. Dziedzic T, Pera J, Slowik A, Gryz-Kurek EA, Szczudlik A. Hypoalbuminemia in acute ischemic stroke patients: frequency 
and correlates. Eur $J$ Clin Nutr. 2007;61:1318-22.

6. Javid RA, Bhatti A, Azhar MA. Frequency of Hypoalbuminemia in Patients with Ischemic Stroke. PJMHS. 2016; 10: 1-3

7. Boehme AK, Esenwa C, Elkind MSV. Stroke Risk Factors, Genetics, and Prevention. Circ Res. 2017;120:472-95.

8. Ozougwu O. The pathogenesis and pathophysiology of type 1 and type 2 diabetes mellitus. J Physiol Pathophysiol. 2013;4:46-57.

9. American Diabetes Association. Standards Of Medical Care In Diabetes 2017. J Clin Appl Res Educ. 2107;40.

10. Dehghan P, Pourghassem Gargari B, Asgharijafarabadi M. Effects of High Performance Inulin Supplementation on Glycemic Status and Lipid Profile in Women with Type 2 Diabetes: A Randomized, Placebo-Controlled Clinical Trial. Health Promot Perspect. 2013;3:5563

11. Alish CJ, Maki KC, Garvey WT, Sacks G. A Diabetes-Specific Enteral Formula Improves Glycemic Variability in Patients with Type 2 Diabetes . Diabetes Technology and Therapeutic. 2010;12:419-424

12. Kellum JA, Lameire N, Aspelin P, Mehta RL, Barsoum RS, Murray PT, et al.

KDIGO AKI Work Group Members. :39. 